\title{
An Analysis of Toni Morrison's God Help the Child from the Perspective of Trauma Theory
}

\author{
Liting Wang \\ School of Foreign Languages \\ Anshan Normal University \\ Anshan, China
}

\begin{abstract}
Nobel Prize winner Toni Morrison is not only an African American woman writer, but also one of the world's most outstanding novelists. Her work portrays the traumatic history of African Americans that they have been suffered for more than a century. Morrison has published 11 novels since the 20th century, all these novels deal with the trauma of the blacks. God Help the Child was published on April 30, 2015. In this book, Morrison once again touched the theme of the trauma of the black offspring, especially the impact and disturbance on the growth of black children in their childhood. This thesis analyzes the cause of the protagonist Bride's childhood trauma as well as her and her lover Booker's recovery process of getting out of their childhood trauma with the help of trauma theory.
\end{abstract}

Keywords-Morrison; God Help the Child; childhood trauma

\section{INTRODUCTION}

Toni Morrison is the only African-American woman writer that won the Nobel Prize for literature. She has published 11 novels till this day: The Bluest Eye, Song of Solomon, Sula, Tar Baby, Beloved, Jazz, Paradise, Love, A Mercy, Home, and God Help The Child which was newly published in 2015. Although there have been different kinds of reviews of Morrison's latest work, the novel has attracted much attention from abroad and home. The comment of Professor Wang Shouren and Wu Xinyun is that it is still "beautifully and poetically written". In her previous ten novels, Morrison, with her profound understanding of American history and culture, her strong political sensitivity and the sense of social responsibility, describes the historical background and life status of African Americans. In her latest work God Help the Child, Morrison once again takes trauma as an important theme, she discusses the endless pain and trouble brought by childhood trauma in one's personal growth. This shows the profound humanistic care of this contemporary female writer. The background of God Help the Child is the contemporary American society in the 21st century. The protagonist Bride is a beautiful, confident, successful young black woman. She is 23 years old and a regional manager for a cosmetics company. She started her own cosmetics brand, went on to a successful career and had a boyfriend, Booker, who she fell in love with. However, in Bride's childhood, her light-skinned mother despised Bride's dark complexion and showed her indifference, so that she did not enjoy the maternal love she longed for so much. The lack of maternal love has left dark childhood memories for Bride, and also brought troubles to her later life. When Bride's career and love were going smoothly, her boyfriend Booker who had spent half a year with her suddenly left her without any warning, leaving her with the words "You not the woman I want". And after that, Bride took some money and presents to visit a parolee woman with the name of Sophia, who was mistakenly accused by Bride in her childhood and was sentenced to go to prison. Bride comes with the hope of making up for her guilt, only to be severely beaten by Sophia. The emotional frustration caused by her boyfriend's departure and the physical damage caused by the beating leave Bride in a situation of emotionally and physically exhausted. So she sets aside her promising career to search for Booker, trying to find the root of her pain and find a way to heal it.

\section{TRAUMA AND CHILDHOOD TRAUMA}

Morrison pays special attention to the national trauma of African Americans, and shows her deep concern for the living condition of African Americans. Trauma is one of the important themes in Morrison's novels, especially the discrimination against black women and black children. Racism and sexism make it very difficult for them to seek self-growth in a healthy way. Morrison showed us how the national trauma constructed from individual trauma by outlining the black history from the early days of slavery to the 20th century through the characters in her novels. Almost every character in the novel has the experience of being abused either physically or psychologically, so the trauma does not refer to individual trauma, but a collective group trauma.

In medicine field, trauma refers to the destruction of the human body caused by violence. While in literature, trauma mainly refers to a life experience caused by various unfortunate experiences. Since the common response to violence is to keep it out of our consciousness, so when something too horrible to be spoken publically happened, this experience became "unspeakable". They are unspeakable because they are too painful even to mention them. Freud believed that an experience is called a trauma if it causes the mind to be subjected to an experience so severely that it cannot seek adaptation in a normal way for a very short period of time, thus permanently disturbing the distribution of the effective capacity of the mind. According to an 
American scholar Cathy Caruth, she believes that trauma is a highly unusual experience that describes a sudden or catastrophic event. People's response to the disaster event is usually delayed and there are recurrent hallucinations and other uncontrollable phenomena. The development of early childhood has a crucial impact on the quality the child's entire life. The quality of development is influenced by many factors in the biological and social environment. Among them, the upbringing experience and psychological trauma in early childhood have a profound influence on children's psychosocial development. Even in adulthood, many adult psychological problems or mental disorders are closely related to trauma in early childhood. Although most people cope well with general stress events, traumatic events or situations can cause pain for almost everyone and are prone to long-term negative effects. Traumatic events can be experienced by someone themselves, or by seeing or hearing what happens to others. Research shows that traumatic events are not uncommon in real life. About $68 \%$ of children and adolescents before the age of 16 have experienced or witnessed traumatic events. Maltreatment (physical abuse, sexual abuse, and emotional abuse), neglect and separation are major events that cause trauma responses or related disorders in children and can seriously affect their psychosomatic development. The prevalence of emotional abuse and its influence on children's psychosocial development even exceed physical abuse. Neglect, although it may be malicious neglect of care, is often related to the ignorance of the foster, such as the foster education level is not high, lack of education knowledge, no time to care, etc. So the negative consequences of neglect are often more insidious but widespread. For example, physical neglect is the un-satisfaction in the sensitive period when infants and young children need to be nursed in the form of physical contact like hugs and caresses. For infants and young children, attachment to their mothers has survival significance, and long-term separation or loss of parents during this period means that attachment is destroyed, which is also one of the important traumatic events in childhood.

\section{CAuses OF ChILDHOOD TRAuma}

In an environment of social discrimination, the aesthetic value of black and white skin color distorts the mind of the black group, causing not only black discrimination against black, light color discrimination against dark color, but also self-discrimination against oneself. Some parents even discriminate against their own children. In God Help the Child, Bride was abandoned by his father and alienated by his mother because of her dark skin at birth. The causes of childhood trauma of the main characters in the novel are absence of maternal love, the society's discrimination against dark skin and the psychological damage caused by sexual abuse.

\section{A. Absence of Maternal Love}

Bride's father suspected that she was not his child by blood. He treated her like a stranger or even an enemy. He did not want to hug or touch his children. Although Bride is her mother's only child, she seldom has her mother's warmth to accompany her in the growing process. Her memories of her mother are cold and harsh. When Bride was little, Bride wanted so much to feel the caress of maternal love that she even made the mistake of expecting her mother to slam her with her hands in order to feel her mother's touch.

In Bride's childhood, she could not get any care at home and was bullied and ostracized everywhere in the society when she grew up. When Bride was six years old, she was cursed by the landlord because she saw the landlord abuse a young boy sexually. But Bride's mother asked her to "shut up", this experience caused her unable to speak out even for herself when she was bullied at school. These curses and bullies caused indelible damage to her young mind. At the age of eight, Bride won some affection from his mother for accusing Sophia, a white schoolteacher, of sexually abusing her pupils. But Sophia was wronged and Bride lied just to let his mother hold her hand and look at her with pride. The lack of love has made Bride lose her mind and ego. It was with this sense of guilt that Bride wanted to make amends to Sophia 15 years later, but that was misunderstood by her boyfriend Booker and he left her. Bride's mother wouldn't let Bride called her "Mother" or "Mama" but "Sweetness". She believed that in order to minimize the harm to her daughter, she should raise her daughter strictly with tough love. She also believes she is doing so to protect her daughter from too much harm in a society that is graded by skin color. However, her "protection" actually causes the psychological trauma in Bride's childhood. The abnormal love of the mother takes away the happiness of Bride's childhood and destroys their mother-daughter affection. So after growing up, Bride chooses to stay away from her mother and pursue her own life after she can live independently.

\section{B. Society's Discrimination Against Dark Skin People}

The mother's indifference to her daughter is rooted in her color consciousness and color discrimination in the place that she grew up. The novel revolves around the life experience of the protagonist Bride, and reveals the living condition and predicament of African Americans under racial discrimination. Different from previous novels, in this novel Morrison mainly turns her focus on children. In this novel, Morrison discusses the trauma psychology of children and its impact, and deeply exposes the sexual violence, gender politics, racial discrimination and other issues in the American society. Traumatic experiences in childhood can cause severe mental suffering to the victims, leading to constant family estrangement and family affection obstruction.

In this novel, Bride's mother Sweetness is a light color black, and Sweetness' parents' skin color are close white. So in daily life, they are very proud of their skin color, and they think it is an advantage of them to retain personal dignity as a light color black. In the process of her growing up, Sweetness had witnessed discrimination against black skin color people. Because of her parents' light skin color, her mother was not stopped from trying on hats at the mall, and her father was allowed to try on shoes in the front of a shoe store without having to hide in the back room. But her daughter's birth shattered her sense of superiority because her skin was dark black. So, when she saw her new daughter, 
she was at a loss and just kept on saying: "It's not my fault. So you can't blame me. I didn't do it and have no idea how it happened. She was so black she scared me. Midnight black." Although Bride was born in the era when slavery was abolished, her parents and grandparents were affected by racial discrimination. Bride's parents are light-skinned blacks, and his grandparents are not only light-skinned enough to pretend to be white, but also proud of being light black. This deep-rooted self-color discrimination of the black race from generation to generation seriously distorts their mind and makes them blindly follow the aesthetic concept of "white is beautiful" and despise their relatives who have dark skin color.

\section{Psychological Damage Caused by Sexual Assault}

When Bride was six years old, she heard a cat meowing outside the window, so she went to the window and looked out: "I saw not a cat but a man. He was leaning over the short, fat legs of a child between his hairy white thighs. I leaned over the windowsill and stared. The man had the same red hair as Mr. Leigh." Then Bride told Sweetness what she saw. If they turn Mr. Leigh in, they lose would the chance to rent his house. Therefore, Sweetness neither expressed sympathy for the crying boy, nor did she do anything to defend justice. She just warned Bride not to talk about this thing anymore.

This child molestation affair left a huge psychological shadow on Bride. Bride's boyfriend Booker is also a victim of childhood trauma. His trauma came from the death of his brother and was the root was child sexual abuse. Booker originally grew up in a happy family. He had a brother that was close to him, and they had a happy and carefree childhood. But when Booker was eight years old, his brother who was two years older than him suddenly disappeared, plunging the family into turmoil. Booker's tragically-died brother was eventually found six months later, but Booker's nightmare remains. It turns out that a local pedophile seduced, molested and brutally murdered six children, including his older brother. The tragic death of his brother leaves Booker in an abyss of pain and from then on he would not tolerate any abuse of children. When he saw people committing child molestation crime, he would beat them up. When he saw a couple of addicts throwing their two-year-old children in the car crying so that they can use drug, he angrily pulled them out of the car and beat them up. As a result, he was fined for disturbing the peace. Booker went through college and graduate school with that trauma.

The passing of time did not diminish his affection for his brother, and when he came home and saw the room he had shared with his brother was completely changed, he was furious. Later he put forward to establish a fund with the name of his elder brother, but the family does not support. Booker was very angry and after quarrelling with family he run away from home angrily. Witnesses, like victims, suffer from confrontations triggered by trauma. It is very difficult for a witness to keep his head clear, to have a holistic view of the event at the time, to remember all the details, to connect all the details together. It's even harder to find the right and persuasive words to convey what you have seen and heard to others. So those who try to describe the atrocities they see also have the risk of being questioned. When someone speaks out about an atrocity, he or she can be stigmatized in a similar way.

\section{Recovery of Childhood Trauma}

On the on hand, the victims want to deny the existence of the atrocity, but on the other hand they desire to reveal it to the world. This is the major conflict within themselves and the biggest obstacle to its healing. Survivors of atrocities often tell their stories in highly emotional, contradictory and fragmented ways and this undermine their credibility, leading the victims to a dilemma over whether to tell the truth or remain silent. Only with a thorough understanding of the truth will the survivors be able to set out on the road to recovery. Unfortunately, most of the time, the power of silence won. Traumatic experiences are not expressed in words, but in the form of traumatic syndromes.

Because traumatic syndromes have some same underlying characteristics, the trauma recovery generally follows the same path. The main recovery stages are: building a sense of security, restoring the true fact about traumatic events, and repairing the connection between survivors and their communities. Morrison shows the readers the characters' childhood experience, the formation process of adult trauma and the specific manifestation after the trauma. The exposure of their trauma is also the process of trauma recovery. In Morrison's novels, the collective strength of the black community and its own efforts are always the best way to help the victims to get over their trauma. Sethe and Denver in Beloved restored their normal lives with the help of the black community. Frank and his sister in the novel Home returned to their spiritual home under the care of the black sisters. In God Help the Child, Booker put down his painful childhood memory with the help of his aunt. When Booker's aunt, who had taken care of him, was suddenly caught in a fire and her life was in danger, Bride and Booker accompanied her to the end of her life.

In the process of helping his aunt, Booker and Bride found their old days' warmth. And the coming of new life that they conceive brings hope to their lives again, they believe this child can "Immune to evil or illness, protected from kidnap, beatings, rape, racism, insult, hurt, self-loathing, abandonment. Error-free. 11 goodness. Minus wrath."

Due to the alienation of his mother and disapproval of his father, Bride suffered great trauma in her childhood. She also suffers untold pain from witnessing her neighbor's child being sexually abused. However, Bride also heals her own childhood trauma by offering help to others in the pursuit of her beloved Booker. What she saw and heard during the trip also enriched her and she became stronger and independent. Bride is taken in by a kind couple because of an accident on the road. The couple also adopted Rain, a white girl. Rain's life is very tragic. She was forced to be a child prostitute by her own mother when she was a little child. But Rain was swept out of her own home by her mother because she offended a guest, and Bride "felt a companionship that was surprisingly free of envy. Like the closeness of schoolgirls." As a black woman, Bride did not hesitate to protect a white girl regardless of her own safety when she was in danger. In 
fact, the process of helping others is Bride's self-healing and recovery of herself.

\section{CONCLUSION}

Compared with Morrison's other trauma novels, God Help the Child has many distinct features. First of all, Morrison sets the story's background in the contemporary era. The black and white people in the novel are friends with each other. This setting is significantly different from Beloved and The Bluest Eye. In this novel, Morrison does not reflect racial discrimination by depicting the conflict between blacks and whites, but shows such a fact through the different classes within the blacks. The light-skinned blacks have a sense of superiority, imagining themselves as white and discriminating against darker blacks. Bride is a darkskinned child. She is beautiful, confident and independent. Despite suffering from childhood trauma, she did not indulge in the confusion and pain caused by the trauma, but chose to distance herself from her mother and actively enjoy her own life. Secondly, this novel is no longer a sad and scary story, it moves away from the seemingly optimistic ending of Beloved. With Bride, Morrison changes the images of black women struggling in her previous works and demonstrates her firm faith in the progress of human society. From the bitter memory of the black girl's trauma to the sincere blessing for the unborn Child, Morrison shows her expectations for civilization and development to the readers, and expresses her good wishes for humanity to get rid of the pain. Morrison's adoption of modern background in this novel also indicates that the focus of her novel has shifted from the issue of black race to the more general issue of social ethics. As she wrote about the definition of color in the book: "It's just a color, abased trait, not a flaw, not a curse, and not a blessing, not a sin."

\section{REFERENCES}

[1] A, Walker, In Search of Our Mothers' Gardens, London: Phoenix, 2005 , p. 290.

[2] C. Cathy. Unclaimed Experience: Trauma, Narrative and History. Baltimore and Marryland: Johns Hopkings UP, 1996.

[3] C. Linder. Post Trauma Stress Disorder [J]. Pediatrics in Review, 2008, 29 (3) : 103-104.

[4] M. Toni. God Help the Child. New York: Alfred A. Knopf, 2015. 